\title{
Postural balance and functional independence of elderly people according to gender and age: cross-sectional study
}

\section{Equilíbrio postural e independência funcional de idosos de acordo com o sexo e a idade: estudo transversal}

\author{
Helen Benincasa Nakagawa', Juliana Rizzatto Ferraresi", Melina Galetti Prata'I", Marcos Eduardo Scheicher ${ }^{\prime V}$ \\ Universidade Estadual Paulista, Marília, São Paulo, Brazil
}

IPT. Physiotherapist, Department of Physiotherapy and Occupational Therapy, Universidade Estadual Paulista "Júlio de Mesquita Filho"(Unesp), Campus de Marília, Marília (SP), Brazil.

"PT. Professor, Department of Physiotherapy, Faculdade Marechal Rondon, São Manuel (SP), Brazil. "IPT, Msc. Physiotherapist, Hospital das Clínicas, Faculdade de Medicina de Marília, Marília (SP), Brazil. vPT, PhD. Adjunct Professor, Department of Physiotherapy and Occupational Therapy, Universidade Estadual Paulista "Júlio de Mesquita Filho"(Unesp), Campus de Marília, Marilia (SP), Brazil.

\section{KEY WORDS:}

Aging.

Postural balance.

Activities of daily living.

Accidental falls.

Drug therapy.

\section{PALAVRAS-CHAVE:}

Envelhecimento.

Equilíbrio postural.

Atividades cotidianas.

Acidentes por quedas.

Quimioterapia.

\begin{abstract}
CONTEXT AND OBJECTIVE: Aging causes changes in men and women. Studies have shown that women have worse postural balance and greater functional dependence than men, but there is no consensus regarding this. The aim of this study was to compare the balance and functional independence of elderly people according to sex and age, and to evaluate the association between postural balance and the number of drugs taken.

DESIGN AND SETTING: Cross-sectional at a state university.

METHODS: 202 elderly people were evaluated regarding balance (Berg Scale), independence (Barthel Index), age, sex, number of medications and physical activity.

RESULTS: The subjects comprised 117 women (70.2 \pm 5.6 years old) and 85 men (71.1 \pm 6.9 years old). For balance, there was no significant difference regarding sex, but there was a difference regarding age ( $P$ $<0.0001)$. For functional independence, there was a difference regarding sex $(P=0.003)$, but not regarding age. The variables of age, medications and physical activity were significant for predicting the Berg score. For the Barthel index, only age and sex were significant. Elderly people who took three or more medications/day showed higher risk of falling than those who took up two drugs/day (odds ratio $=5.53, \mathrm{P}<$ 0.0001, 95\% confidence interval, 2.3-13.0).

CONCLUSIONS: There was no sexual difference in relation to postural balance. However, people who were more elderly presented a high risk of falling. Functional dependence was worse among females. There was an association between the number of medication drugs and risk of falling.
\end{abstract}

\section{RESUMO}

CONTEXTO E OBJETIVO: O envelhecimento provoca alterações em homens e mulheres. Estudos mostraram que mulheres têm pior equilíbrio postural e maior dependência funcional do que homens, mas isso não é consenso. O objetivo deste estudo foi comparar o equilíbrio e a independência funcional de idosos por sexo e idade, e avaliar a associação de equilíbrio postural com o número de medicamentos ingeridos. TIPO DE ESTUDO E LOCAL: Estudo transversal em uma universidade estadual.

MÉTODOS: 202 idosos foram avaliados quanto ao equilíbrio (Escala de Berg), independência (Índice de Barthel), além da idade, sexo, número de medicamentos e atividade física.

RESULTADOS: Os sujeitos foram 117 mulheres (70,2 \pm 5,6 anos) e 85 homens (71,1 $\pm 6,9$ anos). No equilíbrio, não houve diferença significativa por sexo, mas houve por idade $(P<0.0001)$. Para a independência funcional, houve diferença por sexo $(P=0,003)$, mas não por idade. As variáveis idade, medicação e atividade física foram significativas para predizer o escore de Berg. Para o índice de Barthel, apenas a idade e o sexo foram significativos. Idosos que ingeriram 3 ou mais medicamentos/dia mostraram maior risco de cair do que os que ingeriram até 2 drogas/dia (odds ratio $=5,53, P<0.0001$, intervalo de confiança de $95 \%, 2,3-13,0)$.

CONCLUSÕES: Não houve diferença entre sexos em relação ao equilíbrio postural; idosos mais velhos, contudo, apresentaram grande risco de cair; a dependência funcional foi pior no sexo feminino. Foi encontrada associação entre número de medicamentos utilizados e risco de cair. 


\section{INTRODUCTION}

The global population is aging at an unprecedented rate. In $2012,23 \%$ of the population in the more developed regions and $9 \%$ in the less developed regions were aged 60 years or over. ${ }^{1}$ It has been estimated that by 2050 , the proportion of older citizens will increase to $32 \%$ in developed countries and $19 \%$ in developing countries. ${ }^{1}$

Human aging causes physiological changes such as decreased postural balance, thus increasing the risk of falls. Postural control is considered to be a complex motor skill derived from interaction of multiple sensorimotor processes. ${ }^{2}$ Age-related changes in the peripheral and central components of the visual, somatosensory and vestibular systems can be expected to affect balance and mobility.

One-third of people aged 65 years and over fall one or more times a year. Among community-dwelling older people, the cumulative incidence of falls ranges from 25 to $40 \%{ }^{3}$ Falls have been correlated with a number of different risk factors. Some of these, like age or sex, cannot be altered. In a review, Meschial et al. ${ }^{4}$ found contradictory results in several databases concerning the proportion of falls with regard to sex. Four studies reporting that women were mostly affected were identified, while one study indicated that men were more prone to falling.

Prospective cohort studies have indicated that falls seem to be an independent determinant of functional decline and dependency in activities of daily living (ADLs) in a general elderly population. ${ }^{5,6}$ Sposito et al. showed that women have higher dependence than men in carrying out activities of daily living. ${ }^{\text {? }}$

Aging causes the appearance of chronic diseases, and consequently there is an increase in the quantity of medication drugs ingested. ${ }^{8}$ Both specific classes of drugs and the total number of drugs may be associated with imbalance ${ }^{9}$ and dependency in activities of daily living.

\section{OBJECTIVE}

The objectives of this study were to compare the balance and level of functional independence of older adults according to sex and age, and to evaluate the association between postural balance and number of drugs taken.

\section{METHODS}

\section{Design, participants and ethics}

A cross-sectional study was conducted between 2009 and 2013 in the city of Marília, São Paulo, Brazil. A convenience sample of 209 community-dwelling elderly individuals was recruited at two basic healthcare public units, four healthcare public centers, five community centers and two geriatric clinics. Of the 209 participants initially recruited, 7 were withdrawn because they did not meet the inclusion criteria. Thus, a total of 202 elderly people were enrolled in the study. The study design can be seen in
Figure 1. The following inclusion criteria were used: age 60 years or older; living in the community; and independent gait (without gait assistance device). The following exclusion criteria were used: cognitive impairment detectable by means of the minimental state examination (MMSE), with the following cutoffs: 20 for illiterates; 25 for schooling level of 1 to 4 years; 26.5 for 5 to 8 years; 28 for 9 to 11 years; and 29 for higher levels of education; ${ }^{10}$ and factors that interfere with corporal balance, such as: sequelae of neuromusculoskeletal diseases (stroke or Parkinson's disease), uncorrected visual problems, orthostatic hypotension and continuous use of sedatives, antidepressants and hypnotics. The elderly subjects were classified as sedentary or active according to the criteria of the Brazilian Society of Sports Medicine and the Brazilian Society of Geriatrics and Gerontology. ${ }^{11}$

Written informed consent was obtained from all patients before enrollment. The study was submitted and approved by the Research Ethics Committee of the School of Philosophy and Sciences, Universidade Estadual Paulista (UNESP), Marília, São Paulo, Brazil. It was carried out in accordance with Resolution no. 196/96 of the National Health Council.

\section{Outcome measurements}

Data were collected via face-to-face interviews with researchers. Within the scope of the present study, the subjects were asked for demographic information such as age, diseases presented and medications used.

The participants were evaluated regarding their balance using the Berg Balance Scale (BBS) and their functional independence in daily activities was evaluated using the Barthel Index (BI).

\section{Balance}

The BBS, which measures "functional balance," has three dimensions: maintenance of a position, postural adjustment to voluntary movements and reaction to external disturbances. The subjects'

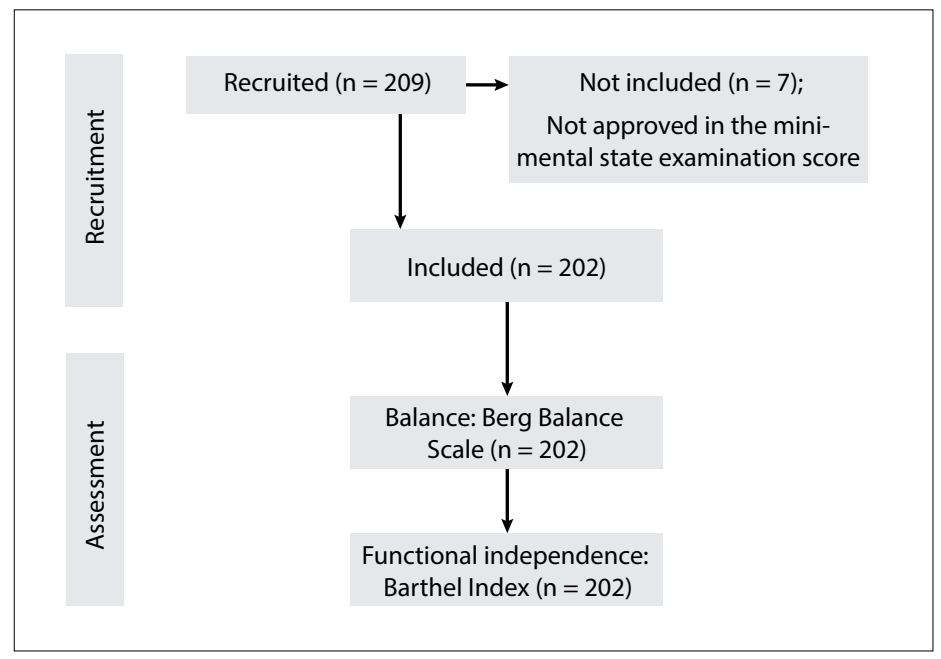

Figure 1. Procedures for data collection. 
performance in each of 14 activities is measured on a five-point ordinal scale ranging from 0 to 4 ( $0=$ unable to perform; $4=$ independent), such that the aggregate score ranges from 0 to 56 . Scores of 48 and less indicate inability to walk independently and safely in daily life and a greater risk of falls. ${ }^{12}$

\section{Functional independence in daily life}

The $\mathrm{BI}$ is a reliable and valid tool measuring overall disability that represents a subject's ability to perform tasks within activities of daily living. It has been recommended for functional assessments on older people. The version used here evaluated functional independence in relation to 10 activities: feeding, bathing, grooming, dressing, bowel care, bladder care, toilet use, transfers, walking and stair climbing. The overall score is obtained by attributing points to each category, depending on the time taken and assistance needed by each patient. The score ranges from 0 to 100 , in 5 -point intervals, and the higher the score is, the more independent the patient is. ${ }^{13}$

\section{Data analysis}

The Kolmogorov-Smirnov test was used to determine the data distribution. The Mann-Whitney test was used for comparisons between the genders. Correlations between drugs used and the BBS were made using the chi-square test (with Yates correction), with the cutoff point $\leq 48$ in BBS for greater risk of falls. ${ }^{12}$ Comparisons between the subjects' ages were made using oneway ANOVA with Dunn's post-test. To analyze the effect of independent variables on the dependent variable (Berg or Barthel), a multiple linear regression model was constructed by means of the Enter method (forced input). R2 was analyzed to ascertain the coefficient of determination of the percentage variation explained by the model. ANOVA for repeated measurements was used to compare the Berg and Barthel scales; however, in order to analyze the influence of factors such as age, sex, medication and physical activity, these were included as covariables (ANCOVA). Furthermore, in order to control for the effect of covariables regarding the correlation analysis between Berg and Barthel, a partial correlation analysis was performed. Pearson's correlation test was performed to analyze the correlation without controlling for covariables. The data were analyzed using the SPSS software, version 19.0 for Windows, and $\mathrm{P} \leq 0.05$ was accepted as significant.

\section{RESULTS}

Among the 202 elderly people studied, 117 were women (57.9\%) and 85 were men $(42.1 \%)$. With regard to schooling level, 12 participants $(5.94 \%)$ were illiterate, $71(35.14 \%)$ had attended school for $1-4$ years, 43 (21.32\%) for 5-8 years and 76 (37.62\%) for more than 8 years. Table 1 shows the characteristics of the subjects of this study.
The BBS scores showed significant differences between the age groups (60-69 years, $70-79$ years and $\geq 80$ years), with lower scores in older age groups. For the Barthel index, there was no significant difference (Table 2), although in older age groups, the scores were lower, thus indicating greater reliance in the subjects' activities.

The Berg and Barthel scales showed a significant positive correlation. When the variables (age, sex, medication and physical activity) were controlled for, the correlation strength was lower, thus indicating that these variables had an important effect (Table 3).

The degree of balance was found to be lower among the women than among the men $(51.5 \pm 4.3$ and $51.8 \pm 3.3$, respectively; $\mathrm{P}=0.08)$. There was no significant difference in postural balance between the sexes (Figure 2).

Figure 3 presents the Barthel scale and shows that the men had a higher average score $(99.7 \pm 1.7)$ than the women $(98.4 \pm 2.9)$, thus indicating greater dependence among the women than among the men in the tasks evaluated by the scale $(\mathrm{P}=0.003)$. The regression analysis confirmed these data and showed that being a woman contributed towards having a worse Barthel index score (Table 4).

Table 1. Subjects' characteristics

\begin{tabular}{lccccc} 
& Women & $\begin{array}{c}\text { Median } \\
(\text { IQR) }\end{array}$ & Men & $\begin{array}{c}\text { Median } \\
(\text { IQR) }\end{array}$ & P \\
\hline $\mathrm{N}$ & 117 & - & 85 & & - \\
$\begin{array}{l}\text { Age (years) } \\
\pm \text { SD }\end{array}$ & $70.2 \pm 5.6$ & $70.0(8)$ & $71.1 \pm 6.9$ & $71.0(10.5)$ & 0.17 \\
$\begin{array}{l}\text { Drugs/day } \\
\pm \text { SD }\end{array}$ & $2.6 \pm 1.9$ & $2.0(3)$ & $2.58 \pm 2.6$ & $2.0(3)$ & 0.09 \\
$\begin{array}{l}\text { MMSE } \pm \text { SD } \\
\text { Physically }\end{array}$ & $26.4 \pm 2.4$ & $27.0(3)$ & $27.2 \pm 2.2$ & $28.0(3)$ & 0.02 \\
\hline $\begin{array}{l}\text { active } \\
\text { Fallers }\end{array}$ & $23(61.5 \%)$ & - & $47(54 \%)$ & - & 0.45 \\
\hline
\end{tabular}

$\mathrm{SD}=$ standard deviation, MMSE = mini-mental state examination, $\mathrm{IQR}=$ interquartile range.

Table 2. Comparison of scores on Berg Balance Scale (BBS) and Barthel Index (BI), according to age groups

\begin{tabular}{|lcccc} 
& $60-69$ years & $70-79$ years & $\geq 80$ years & P-trend \\
\hline BBS & $53.1 \pm 2.3^{*, \dagger}$ & $51.3 \pm 3.9^{\dagger}$ & $44.2 \pm 7.4$ & 0.000 \\
BI & $99.3 \pm 1.9$ & $98.8 \pm 2.4$ & $97.3 \pm 4.9$ & 0.205
\end{tabular}

Values are the mean \pm standard deviation; ${ }^{*} P<0.01$ in relation to age 70-79 years, $+P<0.001$ in relation to age $\geq 80$ years.

Table 3. Correlation analysis with and without controlling for the variables of age, sex, medications and physical activity

\begin{tabular}{|c|c|c|}
\hline Variable control & & $\begin{array}{l}\text { Barthel } \\
\text { and Berg }\end{array}$ \\
\hline \multirow{2}{*}{$\begin{array}{l}\text { Age, sex, medications } \\
\text { and physical activity }\end{array}$} & Correlation coefficient & 0.323 \\
\hline & P-value & 0.0001 \\
\hline \multirow{2}{*}{ Without control } & Correlation coefficient & 0.386 \\
\hline & P-value & 0.0001 \\
\hline
\end{tabular}




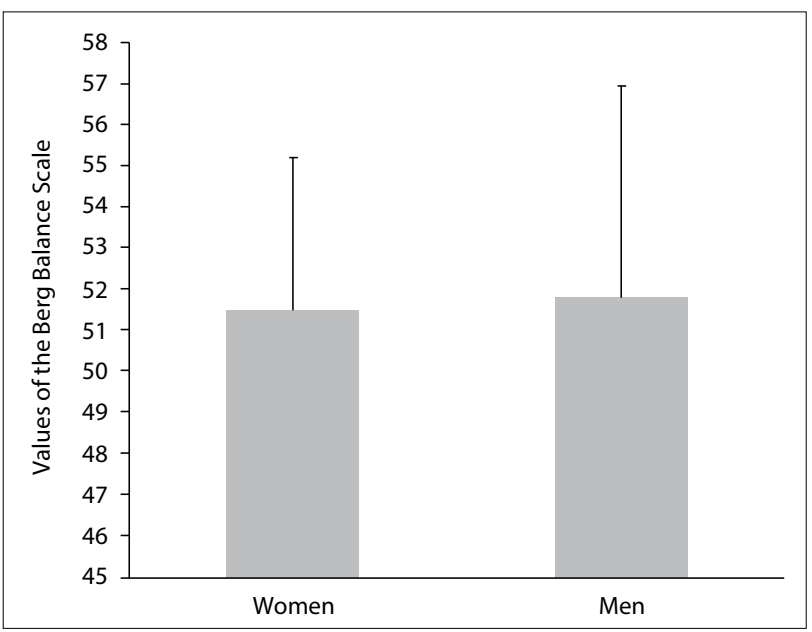

Figure 2. Comparison of scores on Berg Balance Scale (BBS) between women $(n=117$; BBS $=51.5 \pm 4.3)$ and $\operatorname{men}(n=85$; $\mathrm{BBS}=51.8 \pm 3.3) ; \mathrm{P}=0.08$.

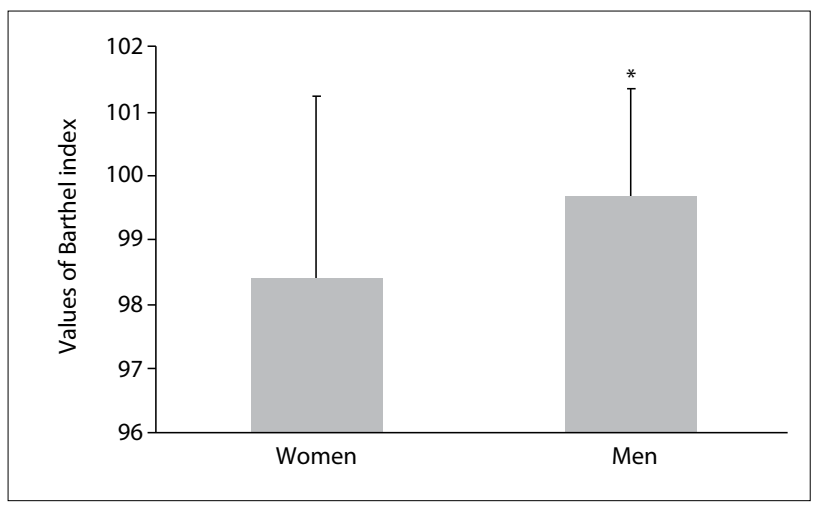

Figure 3. Comparison of scores in Barthel index (BI) between women $(n=117 ; \mathrm{BI}=98.4 \pm 2.9)$ and $\operatorname{men}(\mathrm{n}=85 ; \mathrm{BI}=99.7 \pm$ $1.7) ;{ }^{*} \mathrm{P}=0.003$.

Table 4. Multiple linear regression to analyze the effect of the independent variables on the Berg and Barthel scales

\begin{tabular}{lcccc}
$\begin{array}{l}\text { Dependent } \\
\text { variable }\end{array}$ & Parameters & $\begin{array}{c}\text { Regression coefficient } \\
\text { with } 95 \% \mathrm{Cl} \\
\text { (lower } \mid \text { upper) }\end{array}$ & $\mathbf{R}^{2}$ & P-value \\
\hline Bntercept & $76.458(70.791 \mid 82.126)$ & 0.0001 \\
Berg & Age & $-0.344(-0.424 \mid-0.265)$ & $0.0001^{*}$ \\
& Sex & $-0.662(-1.643 \mid 0.319)$ & 0.369 & 0.185 \\
& Medications & $-0.421(-0.642 \mid-0.200)$ & $0.000^{*}$ \\
& Physical & $1.693(0.710 \mid 2.676)$ & $0.001^{*}$ \\
& activity & $105.642(101.690 \mid 109.594)$ & 0.0001 \\
Barthel & Intercept & Age & $-0.086(-0.141 \mid-0.030)$ & $0.003^{*}$ \\
& Sex & $-1.449(-2.134 \mid-0.765)$ & 0.122 & $0.0001^{*}$ \\
& Medications & $-0.026(-0.180 \mid 0.128)$ & 0.743 \\
& Physical & $0.503(-0.183 \mid-0.183)$ & 0.150
\end{tabular}

*Significant effect of the variable in the regression model for predicting the dependent variable. $\mathrm{Cl}=$ confidence interval.
There was an association between the number of drugs taken and the risk of falling. Elderly people who reported ingesting three or more medications/day presented higher risk of falling than those who reported taking up to two drugs/day (odds ratio = 5.53; P < 0.0001; 95\% confidence interval, CI: 2.3-13.0), considering a cutoff $\leq 48$ points for higher risk of falls on the Berg scale. ${ }^{12}$

Through regression analysis, it could be seen that the variables of age, medications and physical activity significantly predicted the Berg score. In addition, the set of variables inserted in the model explained $36.9 \%\left(\mathrm{R}^{2}\right)$ of the variation in the Berg scores. For the Barthel index, only age and sex were significant, but the regression model indicated that the variables together account for only $12.2 \%$ $\left(\mathrm{R}^{2}\right)$ of the variation of the scores. This indicates that the Barthel score appears to be less influenced by the covariates of age, sex, medications and physical activity than the Berg scale (Table 4).

\section{DISCUSSION}

This study examined some important issues regarding elderly people, including the difference between sex and age groups regarding balance and independence, and the relationship between the risk of falling and the number of drugs ingested. There were no differences in postural balance in relation to sex (Figure 2 and Table 4). These results are contrary to data in the literature. Perracini and Ramos ${ }^{14}$ and Moreira et al. ${ }^{15}$ indicated that women had worse balance than men. The probable reason for our result is that more than $50 \%$ of the elderly people in the sample evaluated here practiced regular physical activity $(61.5 \%$ for women and $54 \%$ for men). The literature provides evidence that older adults who maintain regular physical activity have better postural balance and mobility. ${ }^{16-18}$ Comparison among age groups, regardless of sex, showed significant differences in BBS scores, thus indicating that deterioration of balance is associated with advancing age and that balance among people aged 80 and over is impaired (mean score 44.2), with high risk of falling (Table 2 and Table 4). The deterioration of postural control with age can be explained by decreased cognitive function, declining sensory inputs and motor responses and deterioration of the integration of systems responsible for postural balance.

The Berg and Barthel scales showed a significant positive correlation, but when the variables of age, sex, medication and physical activity were controlled for, the strength of the correlation became lower, thus indicating that these variables had an important effect (Table 3). The variables of age, medications and physical activity significantly predicted the Berg score, thus explaining 36.9\% $\left(\mathrm{R}^{2}\right)$ of the variation in the Berg scores. For the Barthel index, only age and sex were significant, but the regression model indicated that the variables together were responsible for only $12.2 \%\left(R^{2}\right)$ of the variation of the scores. This indicated that the Barthel score appeared to be less influenced by the covariates of age, sex, medications and 
physical activity than the Berg scale. This data are in contrast with the study of Dunlop al., ${ }^{19}$ which found a strong relationship between activities of daily living (ADL) and level of physical activities, age and female gender in older adults.

The present study also examined the relationship between the number of drugs taken and balance, and found that older adults who take three or more drugs/day are at higher risk of falls, according to the Berg scale. The number of drugs taken daily has been identified as an independent risk factor for falls: Campbell et al. found that the total number of drugs was an important predictor of falls among women. ${ }^{20}$

The literature indicates that sex is a factor strongly related to occurrences of functional dependency, and that the chance that women will be dependent is twice as high as for men. ${ }^{21-24}$ Our results showed that men achieved scores that were higher than those of women on the Barthel Index, thus indicating a greater likelihood that women are more dependent than men in relation to activities of daily living (Figure 3 and Table 4). This difference can be explained through two issues: the predominance of non-lethal incapacitating conditions among women (osteoarthritis, osteoporosis and depression) and the greater capacity of women to report their health status than that of men of the same age. ${ }^{21}$ Women have longer life expectancy than men, ${ }^{1}$ thus increasing their risk of chronic diseases, which can lead to disability. Furthermore, women tend to report greater functional difficulties than men. ${ }^{25}$

Analysis on the functional capacity of elderly people can be considered an essential mechanism for more detailed clinical evaluation in the field of gerontology and rehabilitation ${ }^{22}$ as well as for research relating to postural balance.

One of the limitations found in the present study was the difficulty in finding male elderly individuals who were willing to participate and thus being able to make comparisons with equal numbers of men and women. The strengths of this study were the number of participants and the tests used in evaluations, which are easy to apply in clinical practice.

\section{CONCLUSIONS}

The results showed that there was no difference between the two sexes in relation to postural balance in the population studied. However, the older age group presented a great risk of falling. Functional dependence was correlated to sex, such that it was worse among females. Furthermore, there was an association between the number of drugs taken and the risk of falling.

\section{REFERENCES}

1. United Nations. Department of Economic and Social Affairs. World Population Prospects: The 2015 Revision, Highlights and Advance Tables. 2013. Available from: http://esa.un.org/unpd/wpp/Documentation/ pdf. Accessed in 2017 (Mar 27).
2. Horak FB, Macpherson JM. Postural orientation and equilibrium. In: Rowell LB, Shepard JT, editors. Handbook of Physiology: Section 12, Exercise Regulation and Integration of Multiple Systems. New York: Oxford University Press; 1996. p. 255-92.

3. Stalenhoef PA, Crebolder HFJM, Knottnerus JA, van der Horst FGEM. Incidence, risk factors and consequences of falls among elderly subjects living in the community: a criteria-based analysis. European Journal of Public Health. 1997;7(3):328-34. Available from: https:// eurpub.oxfordjournals.org/content/eurpub/7/3/328.full.pdf. Accessed in 2017 (Mar 27).

4. Meschial WC, Nespollo AM, Soares DFPP, et al. Idosos vítimas de quedas atendidos por serviços pré-hospitalares: diferenças de gênero [Elderly victims of falls seen by prehospital care: gender differences]. Rev Bras Epidemiol. 2014;17(1):3-16.

5. Sekaran NK, Choi H, Hayward RA, Langa KM. Fall-associated difficulty with activities of daily living in functionally independent individuals aged 65 to 69 in the United States: a cohort study. J Am Geriatr Soc. 2013;61(1):96-100.

6. Stel VS, Smit JH, Pluijm SMF, Lips P. Consequences of falling in older men and women and risk factors for health service use and functional decline. Age Ageing. 2004;33(1):58-65.

7. Sposito G, Diogo MJDE, Cintra FA, et al. Relações entre bem-estar subjetivo e mobilidade e independência funcional por função de grupo de faixas etárias e de gêneros em idosos [Relationships between subjective well-being, mobility, and independenceas a function of age bracket and gender among the elderly]. Acta Fisiatrica. 2010;17(3):103-8.

8. Secoli SR. Polifarmácia: interações e reações adversas no uso de medicamentos por idosos [Polypharmacy: interaction and adverse reactions in the use of drugs by elderly people]. Rev Bras Enferm. 2010;63(1):136-40.

9. Boyle N, Naganathan V, Cumming RG. Medication and falls: risk and optimization. Clin Geriatr Med. 2010;26(4):583-605

10. Brucki SMD, Nitrini R, Caramelli P, Bertolucci PHF, Okamoto $H$. Sugestões para o uso do mini-exame do estado mental no Brasil [Suggestions for utilization of the mini-mental state examination in Brazil]. Arq Neuropsiquiatr. 2003;61(3B):777-81.

11. Nóbrega AC, Freitas EV, Oliveira MAB, et al. Posicionamento oficial da Sociedade Brasileira de Medicina do Esporte e da Sociedade Brasileira de Geriatria e Gerontologia: atividade física e saúde no idoso [Official thread of the Brazilian Society of Medicine of the Sport and the Brazilian Society of Geriatria and Gerontologia: physical activity and health in the aged one]. Rev Bras Med Esporte. 1999;5(6):207-11.

12. Santos GM, Tavares GMS, Mazo GZ, Virtuoso JF, Souza ACS. Valores preditivos para o risco de queda em idosos praticantes e não praticantes de atividade física por meio do uso da Escala de Equilíbrio de Berg [Predictive values at risk of falling in physically active and no active elderly with Berg Balance Scale]. Rev Bras Fisioter. 2011;15(2):95-101. 
13. Minosso JSM, Amendola F, Alvarenga MRM, Oliveira MAC. Validação, no Brasil, do Índice de Barthel em idosos atendidos em ambulatórios [Validation of the Barthel Index in elderly patients attended in outpatient clinics, in Brazil]. Acta Paul Enferm. 2010;23(2):218-23.

14. Perracini MR, Ramos LR. Fatores associados a quedas em uma coorte de idosos residentes na comunidade [Fall-related factors in a cohort of elderly community residents]. Rev Saúde Pública. 2002;36(6):709-16.

15. Moreira MD, Costa AR, Felipe LR, Caldas CP. Variáveis associadas à ocorrência de quedas a partir dos diagnósticos de enfermagem em idosos atendidos ambulatorialmente [The association between nursing diagnoses and the occurrence of falls observed among elderly individuals assisted in an outpatient facility]. Rev Latinoam Enferm. 2007;15(2):311-7.

16. Weening-Dijksterhuis E, de Greef MH, Scherder EJ, Slaets JP, van der Schans CP. Frail institutionalized older persons: A comprehensive review on physical exercise, physical fitness, activities of daily living, and quality-of-life. Am J Phys Med Rehabil. 2011;90(2):156-68.

17. Intiso D, Di Rienzo F, Russo M, et al. Rehabilitation strategy in the elderly. J Nephrol. 2012;25 Suppl 19:S90-5.

18. Macedo DO, Freitas LM, Scheicher ME. Preensão palmar e mobilidade funcional em idosos com diferentes níveis de atividade física [Handgrip and functional mobility in elderly with different levels of physical activity]. Fisioter Pesqui. 2014;21(2):151-5.

19. Dunlop DD, Song J, Arntson EK, et al. Sedentary time in US older adults associated with disability in activities of daily living independent of physical activity. J Phys Act Health. 2015;12(1): 93-101.

20. Campbell AJ, Borrie MJ, Spears GF. Risk factors for falls in a communitybased prospective study of people 70 years and older. J Gerontol. 1989;44(4):M112-7.

21. Rosa TEC, Benício MHD, Latorre MRDO, Ramos LR. Fatores determinantes da capacidade funcional entre idosos [Determinant factors of functional status among the elderly]. Rev Saúde Pública. 2003;37(1):40-8.

22. Assis VG, Marta SN, Conti MHSD, et al. Prevalência e fatores associados à capacidade funcional de idosos na Estratégia Saúde da Família em Montes Claros, Minas Gerais, Brasil [Prevalence and factors associated with the functional capacity of the elderly within the Family Health Strategy in the city of Montes Claros, Minas Gerais, Brazil]. Rev Bras Geriatr Gerontol. 2014;17(1):153-63.

23. Nunes MCR, Franceschini SC, Ribeiro RCL, Rosado LEFPL. Influência das características sociodemográficas e epidemiológicas na capacidade funcional de idosos residentes em Ubá, Minas Gerais [The influence of sociodemographic and epidemiological characteristics on the functional capacity of elderly residents in the city of Ubá, Minas Gerais]. Rev Bras Fisioter. 2009;13(5):376-82.

24. Santos KA, Koszuoski R, Dias-da-Costa JS, Pattussi MP. Fatores associados com a incapacidade funcional em idosos do Município de Guatambu, Santa Catarina, Brasil [Factors associated with functional incapacity among the elderly in Guatambu, Santa Catarina State, Brazil]. Cad Saúde Pública. 2007;23(11):2781-8.
25. Campos ACV, Bogutchi TF, Almeida MHM, Campos GV. Prevalência de incapacidade funcional por gênero em idosos brasileiros: uma revisão sistemática com metanálise [Prevalence of functional incapacity by gender in elderly people in Brazil: a systematic review with metaanalysis]. Rev Bras Geriatr Gerontol. 2016;19(3):545-59.

\section{Conflict of interest: None}

Sources of funding: None

Date of first submission: December 5, 2016

Last received: February 9, 2017

Accepted: February 28, 2017

\section{Address for correspondence:}

Marcos Eduardo Scheicher

Departamento de Fisioterapia e Terapia Ocupacional, Faculdade de Filosofia e Ciências, Universidade Estadual Paulista "Júlio de Mesquita Filho" (Unesp)

Av. Hygino Muzzi Filho, 737

Marília (SP) - Brasil

CEP 17525-000

Tel. (+55 14) 3402-1350, ramal 1479

E-mail:mscheicher@marilia.unesp.br 